S. I. RESTORING HUMAN NATURE

DOI: https://doi.org/10.14428/thl.v6i1.61213

\title{
Female Christian Responses to Contexts of Imposed Impostorism
}

\author{
AMY F. DAVIS ABDALLAH \\ Nyack College \\ amy.davis@nyack.edu
}

\begin{abstract}
Many individuals have periodic doubts about whether they belong in the position they occupy. Some find a way to ignore or otherwise move beyond those doubts, especially if they have outward evidence that they do belong, that they are not a fraud, not an impostor. This outward evidence is usually skill and experience. It seems more challenging to move beyond the doubts when the sources of these doubts are not only internal to the person but also external or structural. Systems and structures exist that seem to say to some, "you belong," and to others, "you do not belong." For centuries, women have been told by Christian hierarchical structures that they do not belong in church leadership in spite of evidenced skill. Their female bodies are marginalized in church and society. For our purposes, contexts that tell women they do not belong and are impostors will be named contexts of Imposed Impostorism (II). How do women respond to these contexts? Three choices seem to exist. First, agree and shrink back. Second, overcome Impostor Phenomenon (IP), the internalization that you do not, in fact, belong, and "walk on," doing the work. And third, agree humbly that you do not belong in order to disarm the audience and walk on. The first response seems to have always existed, the second is current since studies of IP are relatively recent, and the third is historical; we are particularly interested in how Teresa of Avila and Katharina Zell enact it. The responses interact with the virtue of humility and gendered stereotypes, and have different measures of power.
\end{abstract}

Keywords: Impostor Phenomenon, Humility, Teresa of Avila, Gender Stereotype, Stereotype Management 


\section{Introduction}

Rev. Tara Beth Leach was prepared. A millennial, she discerned a call to vocational Christian ministry at a young age. Upon completing her undergraduate degree, she became a youth pastor in upstate New York. She continued in full-time ministry and later attended seminary. Her first call to a lead pastor role was at Pasadena Church of the Nazarene. Throughout her journey, however, she was told by many that pastoring, and especially lead pastoring, was not a role for women; her female body did not belong in the pulpit at the head of a church. And yet she walks on, preaching, leading, and writing. In her book, Emboldened: A Vision for Empowering Women in Ministry (2017), she confesses that she felt like she did not belong in seminary or the pulpit, citing Impostor Phenomenon (IP), a feeling that one does not belong or is a fraud in spite of clear evidence to the contrary. ${ }^{1}$ She offers strategies both to overcome IP and to deal with opposition to female leadership in the church. She first needed to to overcome IP, to convince herself that she did in fact belong before she could effectively walk on.

In 16th century Spain, Teresa Sanchez de Cepeda (later St. Teresa of Avila, Doctor of the Church) also discerned a call to the vocational Christian ministry for the women of her time: the convent. While her path was a meandering one, she became an expert on prayer and she began to write in her forties. Today, her works still strongly influence and teach both men and women about prayer. In the 16th century, women were also told that their female bodies did not belong as teachers or leaders of men in the church or society. Teresa's writing does not deny this cultural and Christian understanding of her sex. Instead, she agrees, often citing female inadequacy, lowliness, and even stupidity (Fullam 2014, 193). This is characteristic of The Book of Her Life, a work on prayer that her confessor, Domingo Báñez, only wants men to read (Weber 1990, 77). It seems that her strategy is to agree with the "opposition," thereby disarm it, and be granted a hearing. Unlike Leach, she seems to be confident that she does, in fact, belong; she employs a counterintuitive strategy that gives her an opening so that others might recognize that fact.

\footnotetext{
${ }^{1}$ Leach calls it Imposter Syndrome rather than Impostor Phenomenon. "Phenomenon" will be the preferred term because "syndrome" implies a diagnosable and treatable issue. Impostor Phenomenon is more of an observable feeling that may lead to other issues. IP is an integrated concept that relates to suffering in multiple areas (Jöstl 2012, 110). It is correlated with anxiety, depression, low self-esteem, low conscientiousness, low self-efficacy, narcissism, shame, and perfectionism (Cusack, Hughes, and Nuhu 2013, 74; Lane 2015, 115; Tigranyan et al. 2020, 2). Further, with regard to the Big Five Personality Factors, IP sufferers tend toward neuroticism, thus giving rise to the term, "neurotic impostor" (Cusack, Hughes, and Nuhu 2013, 74; Flora 2016, 76; Lane 2015, 115; Kets de Vries 2005, 110).
} 
Both Leach's and Teresa's contexts tell them they do not belong in positions of Christian influence over both sexes because of their bodies. Leach has the current commonly recognized qualifications for church leadership: a seminary degree and experience. On the other hand, Teresa does not have access to the same education as her male counterparts, but her experience in mystical prayer is a qualification for authoritative writing. Lack of skill is not the disqualifying factor for either woman; female embodiment is. In both contexts, while a woman may have skill and knowledge (outward evidence that she belongs), the context or system calls her an impostor, a fraud, someone who does not belong in spite of evidenced skill. For our purposes, we will call these contexts of "Imposed Impostorism" (II).

II contexts are rife with stereotypes, power structures, and expectations. Each is consequential for those high on the hierarchical ladder as well as those on the lower rungs. Our interest is women who historically stand on the lower rungs in church and society. How does a woman who aspires to or feels called to church leadership respond to this context? When formative people in a woman's life tell her she must be misinterpreting the call of God, how does she respond to these II voices that speak a resounding, "No, not a woman"? We will explore three primary responses to II contexts: shrinking back, doing personal work to overcome IP feelings (Leach), and agreeing strategically and humbly (Teresa). For the first response, we have little evidence of those who shrank back and did not speak, but current research suggests it is a response. The second and third responses are more active and vocal so we do have evidence for them and their enduring voice; these responses display a measure of power and allow the women to "keep walking" in their vocation. For the second, while Leach may be an exemplar of someone who seeks to overcome IP, this choice will not center only on her but will be generalized as a current response to II. And for the third, various historical Christian women, including 16th century contemporaries Teresa of Avila and Katharina Zell agree strategically and humbly with the II context's assessment of women. This agreement is strategic because it disarms their audience and grants them a hearing. This third option will be most developed.

\section{First Response to II: Shrink Back}

Female responses to a context of II can vary; women have choices. One choice is to agree that she does not belong, shrink back and be silent. We have no historical evidence of women making this choice, for it is an argument from silence. We do know that women make that choice today when we study IP. The shrinking back response was not correlated to II contexts, however. IP is usually studied as a crisis 
within the individual and does not take the surrounding context or structure into account. IP is an internal feeling of not belonging while the II contexts are external structures that tell women they do not belong. Whether internal to an individual or external to a structure, not belonging is the connection.

IP sufferers believe themselves to be a fraud or unqualified for a position in spite of clear evidence to the contrary (Clance and Imes, 1978). The world might applaud their clear success, but they are often silent self-humiliators, keeping the secret of their self-perceived incompetence quiet and hidden. Clance and Imes first studied this phenomenon in high-achieving women, but subsequent findings have been mixed; some show a greater prevalence in women and some show no statistically significant difference between the sexes. What is significant, however, is that there is a difference in response to IP between women and men. While men selfunderestimate and rise to the challenge, women self-underestimate and shrink from the challenge (Flora 2016, 77; Langford and Clance 1993, 498; Wosinska, et al. 1996, 232). When men rise to the challenge, their context tells them they do belong. When women shrink, their II context tells them they are right to shrink because they did not belong. ${ }^{2}$

Clance and Imes also observed different tendencies with regard to male and female attribution of success and failure. Women tend to attribute success to chance and failure to themselves, while men tend to do the opposite and attribute success to themselves and failure to chance (Bernard et al. 2017, 156). In other words, women internalize failure and externalize success while men internalize success and externalize failure. This results in two responses that tend to follow gender lines. When men have a feeling of not belonging or of failure, they tend to "fake it 'til they make it," and women tend to withdraw, be silent, or quit.

IP will be explored below as the second response to II. For now, it is enough to say that while we have no historical evidence of who or how many, it is probable that some historical women shrank back from leadership in II contexts like the Church due to their sex. ${ }^{3}$

\section{Second Response to II: Do Personal Work to Overcome IP}

In patriarchal Christian contexts today (II contexts), women may self-assess as unqualified for roles like pastor because pastor is not a role for which they should be

\footnotetext{
${ }^{2}$ The studies that show these gendered differences in response to IP did not also look at race.

${ }^{3}$ Because this paper's interest is women, I will prefer feminine pronouns throughout this paper. This does not exclude males from the same tendencies; our purpose is simply to describe Christian women, not men.
} 
qualified. Perhaps they have never seen a female pastor or have been specifically told that women cannot fulfill that role. They feel like a fraud and want to overcome this feeling. While IP studies are not always correlated to an II context, Tara Beth Leach does make the connection in her book.

In the case of Leach, she was part of the Church of the Nazarene, a Protestant denomination that has historically ordained women. Her place as a leader, however, was still challenged. While there may be theological reasons for this challenge in general, it can be categorized under gender stereotype, for which there are numerous reasons. ${ }^{4}$ Gender stereotypes are strong: they enforce conformity through societal expectation and reward; they exert force against and punish those who do not conform. Psychologists call this force "stereotype threat" and it has potential to affect self-concept and actions (Sikdar, Arijit and Sumit Mitra 2009; Rios, Cheng, Totton and Shariff 2015). Many succumb to stereotype threat by conforming to the stereotype or acting in congruity with it. To display stereotype incongruence like Teresa of Avila, Katharina Zell, or even Tara Beth Leach, usually causes different levels of psychological distress (Cusack, Hughes, and Nuhu 2013, 74; Lane 2015, 115; Tigranyan et al. 2020, 2).

\subsection{IP as a Personal Problem with a Personal Solution}

The problem of feeling like a fraud in spite of evidence to the contrary (IP) is a problem commonly located within the individual. Research shows that most people have experienced IP at some point or another. Some regard it as part of "coming of age" in one's career and see it as particularly prevalent in emerging adults (Lane, 2015). Certainly, when a person begins a career, is promoted, or starts to work for a new organization, they wonder if they belong. IP is sometimes thought of as a crisis of confidence, or an irrational understanding of reality. If it is a personal problem, then, the solution must also be a personal solution. Even when an II context is identified as a factor that contributes to IP, the problem is still treated as personal. That means that those who feel like impostors as well as those who are treated as such are tasked with changing themselves or doing some personal work in order to "keep walking on" in their context. This work is hard and psychologically taxing.

\footnotetext{
${ }^{4}$ Reasons for gender stereotypes are many and varied. Some seem innocent: they are based on observations on how male and female individuals tend to act. Others seem less innocent: their purpose is to control, in that they keep males acting one way and females acting another. Our purpose is not to examine the reasons for gender stereotypes; it is to simply state they exist and have power. They will be further explained below.
} 
Strategies for the work, however, abound and are available for all religions and walks of life. ${ }^{5}$

It is important to note that many IP sufferers want the problem to be solved outside themselves. An IP sufferer deeply longs for external validation. If only someone would validate her, she thinks, she would be okay. Her precarious self-esteem makes her unable to self-validate. Yet when she does receive the longed-for external validation, she discredits it, sometimes even questioning the validator's motives (Lane 2015, 120-121). The only opinions that IP sufferers internalize are the negative ones-both their own and those of others. Female IP sufferers have greatness, but they are also limited, lack self-efficacy, see themselves as less, internalize negative feedback and deflect the positive, all in the context of a stereotype that encourages them be self-abasingly humble. ${ }^{6}$ Her world is fearful and conflicted; no wonder she shrinks back. ${ }^{7}$ At the end of the day, if her IP is personal and not structural, she must self-validate.

If one desires to overcome IP, it seems there is strength in numbers and in education. When IP sufferers participate in studies about IP, learning about the phenomenon is relieving for the participants (Lane 2015, 125). Not only is education helpful, but being with others who suffer from the same phenomenon allows the women to see the truth in others (Clance and Imes 1978, 6). That is, they see a successful person in front of them who calls herself a failure. When she sees the incongruity of another person's self-assessment, she may become more aware of the incongruity of her own self-assessment.

In addition to education and being with others like them, particular exercises and practices exist that may mitigate IP feelings. Mindfulness and dialectical behavioral therapy may help to foster the self-validation that IP sufferers need (Lane 2015, 126). Further, rather than facing challenging situations with predictions of failure, an IP sufferer can learn to predict success and actually achieve it (Clance and Imes 1978, 6). Thus, predicting success may be helpful in transforming her self-concept and experience. And finally, exercises that involve accepting positive feedback and

\footnotetext{
${ }^{5}$ Although this may strike some as an over-generalization, it is not. A Google search for Impostor Phenomenon (or syndrome) easily reveals the abundance of information from a variety of sources, some Christian. And much of it is focused on women.

${ }^{6}$ This expectation will be explained in more detail below in the third response.

${ }^{7}$ Certainly not every female suffers from IP, but a large segment of the population does, both male and female. Clance and Imes (1978) do point out family of origin circumstances that seem to encourage it. It may also be related to the influence of stereotype threat on women as well as people of color; stereotype threat has been shown to affect performance (Bernard et al. 2017; Tigranyan et al. 2020; Coblentz 2017; McGee, 2016; Rios 2015).
} 
imagining others' response to her confessions of tricking them about her success have proven effective (Clance and Imes 1978, 6).

Tara Beth Leach gives solutions for IP in chapter two of Emboldened, "Overcoming Impostor Syndrome." Therein, she defines IP using Sheryl Sandberg's Lean In and counters the impostor feelings in women with interpretation of biblical passages that include women in church leadership. Leach issues an impassioned call for women to be fully themselves, in their own voice, in vocational ministry. She does not call the women to change their context. She rather offers ideas they can internalize to overcome IP personally.

Chapter three is "Breaking Stereotypes." In it, Leach describes gender stereotypes, particularly ones that affect a female pastor. She even points out selfeffacing precursors to "board room" comments a woman might make in order to get others to listen and embrace their ideas. A woman might state, "This might be a bad idea" or "I could be wrong" in order to be heard $(2017,60)$. She again calls her readers to be fully themselves even if being herself might break gender stereotypes. While Leach calls women to an emboldened sisterhood, much of the work necessary to "walk on" is still within the individual. Leach does not want women to shrink back in the face of the II context, even though they might be hurt and held back by that context. She encourages them to do the personal work to overcome IP and break stereotypes so that they can be fully themselves and "walk on" in their calling.

\subsection{Stereotype Management in II Contexts}

Another personal way of dealing with an II context is stereotype management. Stereotype management is a way of changing oneself to better "fit" in an II context. In research about IP, stereotype threat, and people of color in STEM fields, Dr. Ebony McGee coined the term "stereotype management" to refer to "both a process and a learned competency that enables students to recognize and negotiate social and psychological threats to their identities" $(2016,1627)$.

In STEM fields, Students of Color face negative stereotypes that often cause them to drop out, a way to shrink back in response to II. "In the course of their schooling, Students of Color have been taught in myriad ways that their identities - their very bodies-do not fit those of exemplary STEM students" (McGee 2016, 1629). In order to continue studying, they alter themselves and overuse grit to persevere. They employ multiple strategies, and the most interesting one for our purposes is that they give up parts of their racial/cultural identity. One male was told he should forget where he came from so he changed his address from an ethnic neighborhood to a P.O. Box. Another changed his friend group and dropped out of the Latino 
caucus in order to have "better job prospects" (1644-1646). A woman changed her hairstyle and clothing - her entire outward appearance, and "the less she looked like herself, the more her teachers and peers valued her intellect" (1645-1646). In these cases, in order to survive, members of marginalized groups change themselves. In their II context, it seems necessary to these students.

"Walking on" in an II context may look like stereotype management, overcoming IP, or breaking stereotypes. Either way, this second response to the II context locates the problem within the individual. Whether it is a personal altering like those in STEM fields, or an altering of a personal belief system, it tends to be psychologically distressing to overuse grit in a context that calls an individual fraudulent due to their body.

\section{Third Response to II: Agree Humbly and Keep Walking}

In contrast to the first two choices, we have evidence of a third choice from the 16th century that St. Teresa of Avila and her Protestant contemporary, Katharina von Zell made. They verbally agree with society's explicit and implicit abasement of women, the message of their II context, and then they walk on. They simply keep walking; they keep speaking; they keep going in the face of a context that tells them they do not belong. They do not appear to "fake it 'til they make it," for they seem a bit too earnest for that. They do not seem angry or insulted when they agree that they are unworthy and unqualified. They just state it as a fact and then do the job. Their agreement sounds like modesty and humility. This self-effacing humility is a common rhetorical strategy among historic Christian women who rise to leadership in the church. Humility has long been understood as a Christian virtue, yet Teresa and her Protestant contemporary, Katharina von Zell, employ humility in deference to female stereotypes and differently from their male counterparts.

\subsection{Is it Simply Humility?}

As it is a virtue, all Christians are enjoined to pursue humility. Humility is opposed to the vices of pride and pusillanimity, is often synonymous with modesty, and is coupled with another virtue, magnanimity. ${ }^{8}$ Below, we will briefly define humility,

\footnotetext{
${ }^{8}$ Rebecca DeYoung is right to connect IP to the vice of pusillanimity, or "small souledness." The pusillanimous person measures herself in comparison to others, sees herself as less, and then shrinks back from action (DeYoung 2004, 215). Aristotle states that a pusillanimous person sees herself as less than the the truth about her. A vain person sees herself as more than the truth, but a magnanimous person sees herself truly and then fulfills that truth to the extent possible (Keating 2007, 66). She
} 
explore gendered expectations of humility, and delineate what distinguishes the humility that the historic women employ from the humility of their male counterparts.

\subsection{Defining Humility}

\subsubsection{Self-Abasing Humility}

Humility has long been defined as self-abasement. In fact, that seems to be the common colloquial understanding of a humble person: one who says they are less and acts as if they are less than others. This definition of humility is for those who have economic or intellectual lack as well as those who have economic or intellectual prosperity. While the greats like Aquinas define it with more nuance, self-abasement is still a salient theme in their understanding of the virtue. A self-abasing person willingly puts herself down and under others.

Humility as self-abasement continues even though another currently popular idea is that humility is not thinking less of oneself but thinking of oneself less. ${ }^{9}$ C.S. Lewis writes in Mere Christianity that a truly humble person will not say she is humble and will not center the conversation on herself. Instead, those who meet her will be impressed at how interested she is in them (Armstrong, 2015). Even in this sense, she puts herself under others as a kind of self-abasement.

\subsubsection{Humility Before God}

The foundation of humility is an acknowledgement of utter dependence on God. It is only from this foundation that a person might be humble before others, for humility can only begin in a human's understanding that they have nothing good,

knows her gifts and limitations, and has no need to compare herself to others (DeYoung 2004, 217). Magnanimity naturally follows humility as a true self-understanding. A magnanimous person acts for the glory of God, and while she accepts human honor, this is not her primary goal (DeYoung 2004, 221). Her self-concept is not swayed by the words of praise or opprobrium from other humans. Her dependence on God is still paramount and with this foundation, she values herself (220). It is also from this foundation that she pursues the highest virtue, the highest good for the world. God's gifts are for us and others, so the magnanimous person acts courageously for herself and for others. As DeYoung writes, "Humility says, 'apart from [God],' I am nothing and '[I] can do nothing'; magnanimity says, 'He has called me by name, and I am his'; therefore, he is 'able to do immeasurably more than all I ask or imagine, according to his power that is at work within me'" (221).

${ }^{9}$ This idea is broadly misattributed to C.S. Lewis; it is Rick Warren's from A Purpose Driven Life (Armstrong, 2015). 
no gifts without God; all that they are is subject to and flows from God (DeYoung 2004, 218; Keating 2007, 70; Overmyer 2017, 654). Humility may best be "defined as a virtue of the rational appetite that clings to the good. What exactly is this good? The truth of our common dependence upon God" (Overmyer 2017, 657).

It is precisely this dependence on God that opens humans to receive the grace of God which then declares their worth in God's eyes and bestows gifts for service to the world (Bommarito 2018; DeYoung 2004, 216). It is counterintuitive: abject dependence of the creature on the creator opens the creature to receive and value gifts and personal worth in a way inaccessible when depending on the self. The pusillanimous person does not depend on God and thus finds herself inadequate and immobile while the humble person depends on God and is free to act in that dependence (DeYoung 2004, 219). Dependence on God eradicates the need to find one's value in comparison to others. Humility says, "It is not about me. All that I am is dependent on God; all that you are is dependent on God. We are not in a competition but we are all pursuing God." This engenders self-worth, selfacceptance and a kind of God-dependent-limitation-embracing self-efficacy.

Psychologists generally do not describe this foundation as a dependence on God. It can be paralleled, however, with psychological reference to a recognition of one's humanity. A humble person's value is not found in extrinsic measures; rather, it is found in simply being human (Zakrsweski 2016). And since one is always human, neither positive nor negative circumstances or actions change that intrinsic value. Failure for a humble person is an event, not a display of inherent lack of worth or incapability. Humble people accept themselves and their limitations (Zakrsweski 2016; Bommarito 2018). Presumably, they also accept their greatness which lends to a truthful self-understanding.

\subsubsection{Humility Before Others}

Humility before others only grows in the soil of humility before God. Though I have separated them here, they seem to act and develop as one; humility before others is a logical and immediate outflow of humility before God. Aquinas roots humility toward others in humility toward God in this way: when we honor others, we honor God in them. It is all about our dependence on God, our love and reverence for God, becoming our esteem for ourselves and for others because of God in them, God gifting them (Overmyer 2013, 654). This humility as others-orientation lifts others up (LaveLock et al. 2017, 287), seeks to unite with others, lacks envy of others' success (Chancellor and Lyubomirsky 2013, 826-827), and displays charity (Overmyer 2013, 658). 


\subsection{Humility, Modesty, and Gender Stereotypes}

Humility is also frequently conflated with modesty. Many treat both virtues as the same and those that make a distinction are not agreed as to their difference from one another (Swain and Korenman 2018, 509; Bommarito 2018). Aquinas places humility under modesty in the category of temperance. For him, exercising humility is more difficult than exercising modesty (Overmyer 2013, 651). Modesty seems to be centered in the way a person interacts in society while humility is much deeper than outward action.

UMC Bishop Sally Dyck believes women often suffer from too much humility (are pusillanimous), lack confidence, and shrink back from acting on their own (2012, 136). Self-abasing humility is a stereotypically feminine trait (Swain and Korenman 2018, 510); humble passivity and silence has been expected of women in historical Christianity (Fullam 2014, 176). In this context, then, when women self-humiliate they may simply display stereotype congruence. Other particular forms of modesty tend to be required of women more than of men. Women should dress modestly and modestly lack assertiveness (Driver 1989, 374).

Conventionally, women are characterized with more communal attributes like kindness and humility, while men have more agentic attributes, like aggression and decisiveness (Sikdar and Mitra 2009, 2). These reflect the persistence of traditional emphases on niceness and modesty for women and strength and drive for men (Prentice and Carranza 2002, 275). Modesty and humility are not only stereotypes, ${ }^{10}$ but are also gender norms for women (Smith and Huntoon 2013, 447; Wosinska, et al. 1996, 232). Gender role norms are decided by the majority culture, children learn them early, they are maintained by reinforcement or punishment, and they provide guidance for behavior (Mahalik, et al. 2005, 417; Wosinska, et al. 1996, 232). Thus, if humility and modesty are gender norms for women, it is safe to say that women are rewarded for acting modestly in conformity to the norm. This reward of acceptance, kind treatment, or other positive reinforcement would cause continued modest and humble behavior and more rewards. It is not that these virtues are not seen in men. Rather, it is that they are seen and emphasized more in women. Because of the reward, women tend to practice them more as well. ${ }^{11}$

\footnotetext{
${ }^{10}$ Alison Weber notes that humility was especially necessary for female mystics because women were "considered more susceptible than men to delusions" $(1990,47)$. Weber notes the context of the Inquisition that scrutinized whether mystical experience was from God or the devil.

${ }^{11}$ How frequently women and men apologize is related to this finding. In 2010, a recent study showed that men tend to apologize less frequently than women. It was not because men do not apologize; rather it was because women have a "higher threshold" for actions that necessitate
} 


\subsection{Female Humility as Distinct from Male Humility}

While there are no psychological studies of gender norms in the 16th century, it is not a stretch to think that a modest and humble gender norm for women was active at the time. ${ }^{12}$ Within Christianity, men were also expected to be humble; the theologians who described humility and encouraged it were male. It is not uncommon for a Christian, male or female, to humble themself before a declaration of great spiritual import. Saint Paul himself stated he was "chief of sinners" and a "wretched man" because of his continued struggle with sin (1 Tim 1:15, Rom 7:1425). St. Paul's self-abasing shows humility before God as well as humility before others. His example is paradigmatic for those who come after him. It is, however, different from female humility in general Teresa's and Zell's humility in particular.

As a male, educated Jew, and Roman citizen, St. Paul is in a position of privilege in several areas. Roman citizenship grants him certain economic and political rights, and males are understood as the paradigmatic human. Male and human were synonymous at that time and this belief continues for centuries. So, when Paul centers his humility in the common man's struggle, a struggle against sin, he appeals to common humanity. Every human struggles against sin, and the reason is not specific male embodiment; it is rather human embodiment and human action. Actions can change while gendered embodiment remains. ${ }^{13}$ Certainly Paul was humble, stated his humility, and then spoke with spiritual authority.

When Teresa and Zell appeal to their sin or their lack of knowledge, they employ humility in the same manner as St. Paul and his imitators. It is not from the same position (the women are in a position of marginalization), but it is still an appeal to common humanity. They are humble before God and others, recognizing fallibility. In a sense, it was the "way it was done" in spiritual circles. It was a strategy to honor God above the human. Still, Teresa's writings have significantly more humility

apology. In that sense, they tend to think they did more wrong than men, even when the actions judged are the same (Schumann and Ross, 2010). It begs the question whether women apologize more and believe they do more wrong because greater humility has been imposed on them.

${ }^{12}$ Female standards of morality in the 16th century included "chastity, modesty, humility, seclusion, obedience to male authority" Weithaus 1993, 132).

${ }^{13}$ Gendered embodiment is understood as more fluid today than it was in earlier centuries. Several early Christian male writers, who still have a profound influence on Christian theology today, seemed to think that women might become men and their words might therefore have a broad authority and influence. For Jerome, "virile women" were extreme ascetics (Temple-Council, 2019), presumably because this asceticism would change female embodiment by ceasing menses and flattening breasts. There is also evidence of ascetic women posing as men in the fourth and fifth centuries (Adam 2006, 28). 
topics than her male contemporaries, and she is not specific about her sins as others were (Weber 1990, 50-51); that is, she calls herself sinful but does not enumerate her failings.

Further, When Teresa and Zell appeal to their place as a woman or female, they are not simply being humble as any good Christian might. They are placing themselves below the paradigmatic human (man) and agreeing with their society's perception that they had little to offer because they were embodied female. They agree that they do not belong and holler an emphatic "That's right!" to their II context. In so doing, as we shall see below, they counterintuitively make their voice more influential.

\subsubsection{Self-Abasing Humility as a Self-Presentational Strategy}

As Teresa and Zell agree with society's assessment that they are unqualified and then walk on, their words about themselves seem to self-underestimate. Selfunderestimation is currently studied in relationship to both IP and II; we can provisionally use these studies to understand the words of Teresa of Avila and Katharina von Zell. While multiple reasons exist for female self-abasement and verbal self-underestimation, the most interesting for our purposes is that it may be a way to manage others' expectations and others' responses to them. Surprisingly, it is fear of success, not fear of failure that often motivates self-abasement and verbal self-underestimation in a phenomenon called neurotic imposture. Others like them better small, so women stay small in their own eyes and in the way they speak of themselves to the world; they protect themselves from envious rejection. Today, and possibly in the 16th century, women are particularly vulnerable to a need to stay small, especially as they function in male-dominated contexts (Kets de Vries 2005, 111, 113). These are contexts of II, like the university, medicine, and the Church. Stereotype incongruence, or female success in male-dominated careers causes mental and emotional distress; some women avoid it by diminishing themselves and their success (Jöstl et al. 2012, 110). On the outside, neurotic impostors seem engagingly humble and modest when they self-deprecate and underplay their achievements (Kets de Vries 2005, 113). Thus, self-underestimation can be a selfpresentational strategy that makes and keeps friends. ${ }^{14}$

\footnotetext{
${ }^{14}$ Comedian Hannah Gadsby, in her Netflix stand-up special refers to the power of selfdeprecation to make people laugh. "I built a career out of self-deprecating humor, and I don't want to do that anymore," she says, as the audience hushes. "Do you understand what 'self-deprecating' means when it comes from somebody who already exists in the margins? It's not humility. It's humiliation." (qtd in Escobar 2018, 57).
} 
Teresa of Avila focuses on her humble state as a woman when she writes. Both church and society in 16th century Spain abased women, and Teresa verbally agrees with that assessment. Her "writing is full of declarations of lowliness, inadequacy, outright stupidity or wickedness, both her own and that of women generally" (Fullam 2014, 193). Even as she voices her incapability, she still speaks. She rises to the occasion and speaks to the world.

Such self-deprecation and underestimation seems to be a self-presentational strategy: she keeps her friends by saying she is nothing. In Teresa's case, however, it seems that she desires to make friends, not just keep them. Teresa is a woman and a mystic; both characteristics present a reason to reject her voice. In order to gain an audience, she uses a rhetorical strategy that puts her below them. When she states she is less, she verbally agrees with what her audience already thinks, so they are more apt to listen to her words (Fullam 2014, 194). ${ }^{15}$ When she speaks, she is not speaking her own words but God's, as a good mystic would do. She gains an audience by self-deprecation. Teresa seems unconcerned about others' opinion. Her sole goal is to do as God asks and speak as God has called her to speak. Her speaking displays stereotype incongruence.

Teresa's contemporary, Katharina Zell presents herself similarly. While they were both women, Teresa was a nun who spoke on her own authority (and God's) and Zell was a Reformer and a wife, whose authority was somewhat derived from her submission to her husband. Zell points to her position as a wife, a piece of her husband's rib, and notes that he called her his curate (Zitzlsberger 2003, 387-388). Before she spoke, she waited and watched to see if a man would speak; had a man spoken, she "would have remained quiet, as is appropriate for a poor woman" (384). Like Zell, other pamphleteers also wrote of knowing their place even as their writing displayed stereotype incongruence $(385,387)$. To gain an audience, she states she only wanted to be heard as Balaam's donkey. Here, she makes herself sub-human as she compares herself to an animal (Sidwell 2018, 149). Her self-presentation as less than she actually is does not aim to stop others from envying her, but like Teresa, it disarms her audience and helps them listen rather than judge, reject, and silence. Inasmuch as both Zell and Teresa identify as lowly women, they display stereotype

\footnotetext{
${ }^{15}$ Carlos Eire summarizes Weber's description of Teresa as "a posture of modesty and humility that disarms any male critic potentially threatened by her claims; a constant harping on her sinfulness and unworthiness that frames all claims to intimacy with God yet fails to reveal any specifics of her misbehavior; and a deference to authority that couches all outrageous claims - such as that of understanding the Trinity-in a rhetoric of imprecision, that is, in a unique mix of apophatic dumbness and abject weakness of intellect that her male readers could appreciate as properly feminine" $(2019,204)$.
} 
incongruence when they speak to the world. If we look back in history to medieval mystics (Hollywood 2003) or forward to female Pentecostals (Fulkerson 1996) we see a similar vocal self-deprecating "humility" followed by strong influential words to the world.

\subsubsection{Humility before God as a Qualification for Voice}

Teresa of Avila and Katharina Zell did not necessarily call themselves modest or humble; but they did verbalize their lesser state in multiple other ways. Whether this was a simple agreement with their audience's assessment or they actually believed themselves to be less is not clear. ${ }^{16}$ Teresa and Zell are examples of women who did not shrink back, though others may have made this choice. They verbally self-abased multiple times in their writing, but they still wrote; they still spoke. And Teresa even wrote that humility is always situated in relationships. For her, the foundation of humility is a relationship of dependence on God that encourages true self-perception (Fullam 2014, 180-181). For Zell, her very words were dependent on the Holy Spirit overwhelming her, displaying a clear dependence on God. Not only does Zell cite the many biblical women that also spoke, but her vocal dependence on God is a rhetorical device historically used by female preachers (Zitzlsperger 2003, 388). Medieval mystics Hadewijch and Mechthild were also apt to speak of and display their humility before God even as they spoke (Hollywood 2003, 8). Of these four women, we have the most information about the inner soul of Teresa of Avila; when she profoundly engages humility, it does seem that she truly depends on God and is humble in this sense.

And while dependence on God is humility's foundation, God is also the mystic's voice. They do not claim to speak their own words, but rather claim to speak the words of God. Pentecostals and mystics seek to speak the words of God to people like the ancient prophets did, and there is biblical precedence for women taking the

\footnotetext{
${ }^{16}$ For medieval female mystic Mechthild, it is precisely her humble state that allows God to speak through her; God's choice depends on her lowliness and she proves her lowliness in her words (Hollywood 2003, 9). Further, theologian Mary McClintock Fulkerson brings out a similar selfdescription among female Pentecostals. Fulkerson does not feign a full understanding of women in hierarchical Christianity since she is a feminist and thinks the structure should be egalitarian. However, as a feminist, she does believe in empowering all women's voices, so she chose to study female Pentecostals. She observed that when female Pentecostals called themselves nothing or even less than nothing, it made them vessels of God's words to the world in the same way the male Pentecostals were. Their verbal self-denigration made it clear that it was God speaking and not them because they are not worthy to speak on their own (Fulkerson 1996, 284). This echoes Mechthild's claim that God comes to the lowliest and speaks through them.
} 
prophetic role. Miriam (Ex 15:20), Deborah (Judges 4-5), Huldah (2 Kings 22:14-20), Anna (Luke 2:36-38), and the four daughters of Philip were all prophets (Acts 21:89) who spoke the word of God in scripture. Can women, however, speak to people words that are not simply God's but words from their study of God or theology? It seems that men speak words and teach in a way that blends dependence on God with their study. Many of the women mentioned here were not theologically educated due to their sex or tradition. Thus, to speak as a prophet seems a bit "safer" and more humble for women.

\subsubsection{Humility Before Others as Stereotype Incongruence}

The historical Christian women we are observing self-abase and act modest, but then they speak to the world and display stereotype incongruence. Their foundational self-understanding seems to be in reference to God, not others, and they act in service to others. It is interesting that Teresa states that humility before God has no limits, but humility before others does. As an expert on prayer, Teresa need not take bad advice on prayer (Fullam 2014, 182). This is a prime example of how humility and magnanimity work together; Teresa knows her gifts and need not put herself under another person who tries to teach her. She conflates humility and magnanimity when she sees humility as true self-understanding in relationship with others (180). Fullam writes, "if it is a virtue, humility must also foster the stronger sense of self of 'some old woman' [Teresa] God might be teaching to pray and calling to lead. Her exaggerated claims of inadequacy are a rhetorical mask for a bold stance of self-assertion and resolve, the humility of the oppressed" (2014, 194). Teresa seems the perfect blend of humility and magnanimity, ${ }^{17}$ coupled with a selfpresentational strategy to amplify God's voice through her. Zell is rather similar.

When Teresa of Avila and Katharina Zell self-efface as "just women," they employ a self-presentational strategy that actually frees them to be the person God has called them to be. It is different from the stereotype management that STEM students apply. In both cases, the individuals have the "right" skills, but the "wrong" bodies. In stereotype management, the individual changes herself in order to "fit in" to the expectations of the II context. The STEM context calls them a fraud because of their body or background, so they change how they present their body and background. Stereotype management is a masking of personal identity. It agrees with the II context's marginalization of one's body, and then it seeks to make that

\footnotetext{
${ }_{17}$ Weber notes that Teresa calls a deep sense of worthlessness false humility, and the right to receive God's love as true humility $(1990,75)$. This reflects humility and magnanimity combined.
} 
body more agreeable to the context. Stereotype management's agreement seems to be a quiet agreement that results in personal change.

When Teresa and Zell agree with the marginalization of their bodies, it is not quiet. They boldly state their inadequacy and disqualification clearly yet do not seem to change their bodies to make them more agreeable. They also do not seem to rebel against the standards of the II context. They seem to accept them. They accept them and simply walk on, not changing their personal identities.

\section{The Three Responses and Their Power}

Women in II contexts are victims of the power structure, but the responses seem to show different measures of power as well. The first response, to shrink back, is a response of powerlessness. She agrees that she does not belong and does not let her voice be heard.

The second response, to work on oneself, is a response of personal power. The person over whom we have the most influence is ourself, so this response enacts that influence. However, the idea that IP is a personal problem is currently questioned. Ebony McGee titled her recent article for University World News, "Impostor Syndrome? No. Just Racism" (2021). She believes that IP as a self-diagnosis obscures the effect of systemic racism, and misplaces it in the individual rather than the structure that causes the person to feel like an impostor. It is not in their head; it is an external structure that tells them they do not belong, a context of II.

Harvard Business Review also recently published an article, "Stop Telling Women They Have Impostor Syndrome." Authors Ruchika Tulshyan and Jodi-Ann Burey point out that the development of IP in the 1970s "excluded the effects of systemic racism, classism, xenophobia, and other biases, [and] took a fairly universal feeling of discomfort, second-guessing, and mild anxiety in the workplace and pathologized it, especially for women" (2021). Through the compelling stories and research, Tulshyan and Burey suggest fixing the overall biases of the system, not the IP response of the individuals affected by the system. Rather than personal power, then, some would call for community power to create an unbiased structure.

As for the third response, it is subversive power, but it subverts only for a time and only for that person. When the women state that they do not belong and then walk on, they may in fact create a space outside of the hierarchical structure, if only for a time and only for a few women. One wonders if that subversive power is actually trying to dismantle the "rules" of the hierarchical structure. Animatou Sow explains her own self-effacing comments in a recent podcast interview on Brene Brown's Unlocking Us. Brown begins by praising Sow and her partner Ann 
Friedman's podcasting skills. Sow responds, "You can be a podcasting legend and still have almost no skills, and so I really want to put forth that that's what's going on with us" (2021). Brown disagrees, and Sow replies, "When I find myself being self-effacing or self-deprecating about this stuff, it's not because I don't think I'm good at what I do ... it's just that other people's criteria is not what interests me" (2021). In this sense, Sow's self-effacing words release her from any obligation to integrate others' criteria in her understanding of personal success. Now, Sow is selfdeprecating with regard to skills, not her female body, so this is different from Teresa and Zell. Perhaps there is some similarity, however, for through their selfeffacing comments, Teresa and Zell create space for their voices that freely speak in their II context. Their verbal agreement and humility open closed doors for their influence. ${ }^{18}$

\section{Conclusion}

Will the church always be an II context for women? Perhaps; it has been for centuries. Certainly, some denominations and contexts, like the Church of the Nazarene, appear inclusive and equitable. Leach's experience on the "inside," however, shows that some vocal members believe women do not belong in leadership. Her work also seems to assume that IP and II are a common experience for women in the church. How much has changed in 500 years?

It is true that current female responses to an II context are different from the 16th century responses of Teresa and Zell. In both time periods, we can assume that some respond to II contexts by shrinking back and silencing themselves; we will never know how many. Teresa and Zell opened up doors for themselves but not necessarily for others. Their words' subversive power was limited. It is also likely that it was psychologically taxing. Would such a strategy be effective today? Is it possible that women today could humbly agree with their disqualifying female bodies and then walk on? There is a subtlety and indirectness to Teresa and Zell's humility-to-open-doors; current western society seems to value directness rather

\footnotetext{
${ }^{18}$ Another current cultural example of the power of agreement comes from a character in "Ted Lasso." This Apple Original is a comedy about a British football team, its coaches, and its owner. The background of one scene is that coach Roy refuses to coach star player Jamie. Head coach Ted invites Roy's girlfriend, Keeley to give advice to Jamie. Keeley says, "I agree." That confuses everyone, but she explains herself. "No, I agree with Roy. Just agree with everything that he throws at you. Really takes the anger wind out of his brat sails" (Ted Lasso 2021). When Keeley agrees with Roy, it does not necessarily mean Roy is right. It just makes Roy less angry and presumably, ready to listen and do what she might want. When Jamie tries it, it is clear that he does not actually agree with Roy, but voices agreement to win Roy over.
} 
than indirectness. Further, there is some evidence that female displays of humility in leadership today lead to a perception of incompetence (Swain and Korenman 2018, 510). For Teresa and Zell, it brought a perception of competence and allowed their voices to endure. Teresa's is particularly strong and influential, though her selfdeprecating comments feel out of place in the 21st century. Although the diminishment of self in order to be a vessel of God's words lends itself to the prophetic office, is it even a reasonable strategy for women in other leadership roles? Is there a different subversive path that might be effective to open doors? When Leach refers to idea-deprecating comments a woman might make before she offers an idea in the "board room," there is a hint of 16th century practice. It is simply a hint, however, for the stated lack is in the idea, not in female embodiment.

Women today are not encouraged to use subversive power. They are encouraged to use personal power to work to overcome IP. Both subversive power and personal power tend to help individuals more than groups, though personal power may create a sisterhood. Like humbly agreeing, enacting this personal power is still psychologically taxing, especially when it involves a degree of stereotype management. Only time will tell if women's personal work on IP in II contexts will allow their voices to stand the test of time.

Is Tulshyan and Burey's clarion call to fix the II system applicable to the church? If it is, the "fix" takes time and may be variously applied. So, the path that women take now is important. Personally, I hope women find a way to walk on and not shrink. The voices of those who respond to II contexts with shrinking silence are forever lost, and the world is a poorer place when we silence its members due to their female embodiment.

\section{Bibliography}

Adam, Ruth. 2006. "Unveiling Precedent: Reclaiming the Power of Women in the Early Church." Senior Honors Theses. https://commons.emich.edu/cgi/viewcontent.cgi?referer=https://www.google.co $\underline{\mathrm{m} / \& \text { httpsredir }=1 \text { \&article }=1064 \& \text { context }=\text { honors }}$

Armstrong, Aaron. 2015. "What C.S. Lewis wrote is more powerful than what he didn't." Blogging Theologically (blog). December 11, 2015. https://bloggingtheologically.com/2015/12/11/what-cs-lewis-wrote-is-betterthan-what-he-didnt/

Bernard, D. L., Q. M. Lige, H. A. Willis, E. E. Sosoo and E. W. Neblett. 2017. "Impostor phenomenon and mental health: The influence of racial discrimination 
and gender." Journal of Counseling Psychology 64(2): 155-166. https://doi.org/10.1037/cou0000197.

Bommarito, Nicolas. 2018. "Modesty and Humility," The Stanford Encyclopedia of Philosophy (Winter 2018 Edition) Accessed March 19, 2021.

https:/plato.stanford.edu/archives/win2018/entries/modesty-humility/.

Brené Brown, host. 2021. Unlocking Us. Brené with Animatou Sow and Ann Friedman on Big Friendship." October 6, 2021. https://brenebrown.com/transcript/brene-with-aminatou-sow-and-annfriedman-on-big-friendship/.

Coblentz, Jessica. 2017. "Ghosts in the Office: The Ecclesiological and Soteriological Implications of Stereotype Threat among Women in Catholic Theology." Journal of Feminist Studies in Religion 33(1): 127-135. https://doi.org/10.2979/jfemistudreli.33.1.11.

Chancellor, J. and S. Lyubomirsky. 2013. "Humble beginnings: Current trends, state perspectives, and hallmarks of humility." Social and Personality Psychology Compass. 819-833. eScholarship, University of California. https://doi.org/10.1111/spc3.12069.

Clance, P. R. and S. A. Imes. 1978. "The imposter phenomenon in high achieving women: Dynamics and therapeutic intervention." Psychotherapy: Theory, Research E Practice 15(3): 241-247. https://doi.org/10.1037/h0086006.

Cusack, C. E., J. L. Hughes and N. Nuhu. 2013. "Connecting Gender and Mental Health to Imposter Phenomenon Feelings." Psi Chi Journal of Psychological Research 18(2): 74-81. https://doi.org/10.24839/2164-8204.JN18.2.74.

DeYoung, R. K. 2004. “Aquinas's Virtues of Acknowledged Dependence: A New Measure of Greatness." Faith and Philosophy: Journal of the Society of Christian Philosophers 21(2): 214-227. https://doi.org/10.5840/faithphil20042125.

Driver, J. 1989. "The Virtues of Ignorance." The Journal of Philosophy 86(7): 373-384. https://doi.org/10.2307/2027146.

Dyck, S. 2012. "Leadership: a calling of courage and imagination." Journal of Religious Leadership 11(1): 113-138.

Eire, Carlos M. N. 2020. The life of Saint Teresa of Avila: a biography. Princeton: Princeton University Press. https://doi.org/10.1515/9780691189376.

Escobar, Allyson. 2018. "Humiliation, Humility, and Hannah Gadsby." America 219 (6): 57.

Flora, Carlin 2016. “The Fraud Who Isn't." Psychology Today. 49(6): 70-77.

Fullam, L. 2014. “Teresa of Avila's Liberative Humility." Journal of Moral Theology 3(1): 175-198. 
Fulkerson, M. M. 1996. "Changing the Subject: Feminist Theology and Discourse." Literature and Theology 10(2): 131-147.

https://doi.org/10.1093/litthe/10.2.131.

Hollywood, A. 2003. "Who Does She Think She is? Christian Women's Mysticism." Theology Today. 60(1): 5-15. https://doi.org/10.1177/004057360306000102.

Jostl, G., E. Bergsmann, M. Luftenegger, B. Schober and C. Spiel. 2012. "When Will They Blow My Cover? The Impostor Phenomenon Among Austrian Doctoral Students." Journal of Psychology 220(2): 109-120. https://doi.org/10.1027/21512604/a000102.

Keating, M. 2007. "The Strange Case of the Self-Dwarfing Man: Modernity, Magnanimity, and Thomas Aquinas." Logos: A Journal of Catholic Thought and Culture 10(4): 55-76. https://doi.org/10.1353/log.2007.0035.

Kets de Vries, M. F. R. 2005. “The Dangers of Feeling Like a Fake." Harvard Business Review 83(9): 2005.

Lane, J. A. 2015. "The Imposter Phenomenon Among Emerging Adults Transitioning into Professional Life: Developing a Grounded Theory." Adultspan Journal 14(2): 114-128. https://doi.org/10.1002/adsp.12009.

Lavelock, C. R., E. L. Worthington, B. J. Griffin, R. C. Garthe, A. Elnasseh, D. E. Davis and J. N. Hook 2017. “Still Waters Run Deep: Humility as a Master Virtue." Journal of Psychology and Theology 45(4): 286-303.

https://doi.org/10.1177/009164711704500404.

Mahalik, James R., Elisabeth B. Morray, Aimée Coonerty-Femiano, Larry H. Ludlow, Suzanne M. Slattery, and Andrew Smiler. 2005. "Development of the Conformity to Feminine Norms Inventory." Sex Roles: A Journal of Research. 52 (78): 417-435. https://doi.org/10.1007/s11199-005-3709-7.

McGee, Ebony. 2016. "Devalued Black and Latino Racial Identities: A By-Product of STEM College Culture?" American Educational Research Journal 53(6): 1626-1662. https://doi.org/10.3102/0002831216676572.

McGee, Ebony. "Impostor Syndrome? No. Just Racism." University World News, June $5,2021$.

https://www.universityworldnews.com/post.php?story=20210531104710417

Overmyer, S. 2015. "Exalting the Meek Virtue of Humility in Aquinas." The Heythrop Journal 56(4): 650-662. https://doi.org/10.1111/heyj.12009.

Prentice, Deborah A. and Erica Carranza. 2002. "What Women and Men Should Be, Shouldn't Be, Are Allowed to Be, and Don't Have to Be: The Contents of Prescriptive Gender Sterotypes." Psychology of Women Quarterly 26: 269-281. https://doi.org/10.1111\%2F1471-6402.t01-1-00066. 
Rios, K., Z. H. Cheng, R. R. Totton and A. F. Shariff. 2015. “Negative Stereotypes Cause Christians to Underperform in and Disidentify with Science." Social Psychological and Personality Science 6(8): 959-967. https://doi.org/10.1177/1948550615598378.

Schuman, Karina and Michael Ross. 2010. "Why women apologize more than men: gender differences in thresholds for perceiving offensive behavior." Psychological Science 21 (11): 1649-55. https://doi.org/10.1177/0956797610384150.

Sidwell, M. 2018. "Did Women Have a Reformation? The Case of Katherine Zell." Puritan Reformed Journal 10(1): 140-153.

Sikdar, Arijit and Sumit Mitra. 2009. "An exploration of gender stereotypes in perception and practice of leadership." Research Online. https://ro.uow.edu.au/dubaipapers/342

Smith, Jessi L., and Meghan Huntoon. 2013. “Women's Bragging Rights: Overcoming Modesty Norms to Facilitate Women's Self-Promotion." Psychology of Women Quarterly 38 (4):447-459. https://doi.org/10.1177/0361684313515840.

Swain, J. and L. Korenman. 2018. "In Their Humble Opinion: How Expressions of Humility Affect Superiors Assessments of Leadership Potential in the US Army." Military Psychology 30(6): 507-527. https://doi.org/10.1080/08995605.2018.1503002.

Ted Lasso. "The Signal." Apple TV video, 37:18. August 27, 2021. https://tv.apple.com/us/episode/thesignal/umc.cmc.3x0zaq4r31lvrgi7eqv0uf5uq?showId=umc.cmc.vtoh0mn0xn7t3c 643xqonfzy.

Temple-Council, Kathryn. 2019. "Feminine agency and masculine authority: women's quest for autonomy in monastic life." Honors Theses. https://scholar.utc.edu/cgi/viewcontent.cgi?article=1238\&context=honors-theses.

Tigranyan, S., D. R. Byington, D. Liupakorn, A. Hicks, S. Lombardi, M. Mathis and E. Rodolfa. 2020. "Factors related to the impostor phenomenon in psychology doctoral students." Training and Education in Professional Psychology. Advance online publication. https://doi.org/10.1037/tep0000321.

Tulshyan, Ruchika and Jodi-Ann Burey. 2021. "Stop Telling Women They Have Imposter Syndrome." Harvard Business Review Digital Articles February 11, 2021. https://hbr.org/2021/02/stop-telling-women-they-have-imposter-syndrome

Weber, Alison. 1990. Teresa of Avila and the Rhetoric of Femininity. Princeton: Princeton University Press. https://doi.org/10.1515/9780691219622.

Wiethaus, Ulrike. 1993. "Female Authority and Religiosity in the Letters of Katharina Zell and Caritas Pirckheimer." Mystics Quarterly 19 (3): 123-135.

Wosinska, Wilhelmina, Amy Dabul, Robin Whetstone-Dion, and Robert Cialdini. 1996. "Self-Presentational Responses to Success in the Organization: The Costs 
and Benefits of Modesty." Basic and Applied Social Psychology. 18 (2): 229-242. https://doi.org/10.1207/s15324834basp1802 8.

Zitzlsperger, U. 2003. "Mother, martyr and Mary Magdalene: German female pamphleteers and their self-images." History (London. Print) 88 (3): 379-392. https://doi.org/10.1111/1468-229X.00268.

Published Online: March 2, 2022 